\title{
First insights into rodent trapping in Oku village, north-west Cameroon, based on interviews with local hunters
}

\author{
Alain D. Missoup, Ngartoubam Didier \\ Ernest C. Keming and Christiane Denys
}

\begin{abstract}
Mount Oku, in the Northwest Region of Cameroon, is known for its rodent diversity. It is located in an area with a high human population density (up to $400 / \mathrm{km}^{2}$ ), resulting in intense pressure on natural resources. Threats to biodiversity include overgrazing by cattle and goats in grassland areas and montane forests, firewood harvesting, agriculture, bee keeping, debarking of Prunus trees for medicinal uses, and bushmeat hunting. We used data from interviews with 106 local hunters to provide insights into rodent trapping in Oku village. Trapping took place primarily in closed canopy forest. The majority of hunters $(88.8 \%)$ set at least 100 traps per week, with a mean of 38 rodents trapped per hunter per week. The two most captured species were the Vulnerable Hartwig's praomys Praomys hartwigi and the Endangered Mount Oku rat Lamottemys okuensis, both of which have declining populations. Rodents were harvested mainly for household consumption and/or local trade, but $65.1 \%$ of interviewees also used $P$. hartwigi for traditional medicine. Our findings suggest that rodent trapping in Oku village requires conservation attention, and that further quantitative studies are needed to assess its sustainability.
\end{abstract}

Keywords Bushmeat, Cameroon, hunting, interviews, Lamottemys okuensis, Oku village, Praomys hartwigi, rodents

Supplementary material for this article is available at doi.org/10.1017/So030605319000772

\section{Introduction}

$\mathrm{T}$ he consumption of meat from wild animals, commonly referred to as bushmeat, is widespread throughout rural and urban areas in the tropics (Milner-Gulland \& Bennett, 2003). It contributes to food security, particularly where fish and farmed meat are unavailable (Bowen-Jones et al., 2003;

Alain D. Missoup (Corresponding author, (D) orcid.org/0000-0002-3018-9188) and Ngartoubam Didier Zoology Unit, Laboratory of Biology and Physiology of Animal Organisms, Faculty of Science, University of Douala, Douala, Cameroon. E-mail admissoup@ymail.com

ERnest C. Keming Kilum-Ijim Forest Project, Kumbo, Cameroon

Christiane Denys (D orcid.org/0000-0002-1519-1546) Institut de Systématique, Evolution, Biodiversité, Muséum National d'Histoire Naturelle, Sorbonne Universités, Paris, France

Received 2 January 2019. Revision requested 12 February 2019.

Accepted 13 June 2019. First published online 1 April 2020.
Brashares, 2003; Fa \& Nasi, 2015) or unaffordable (Junker et al., 2015). Bushmeat also provides an important source of income for rural and forest populations who may depend on wildlife resources to alleviate periods of economic hardship (e.g. crop failures), or to supplement their primary source of income, which is often based on small-scale crop farming (Loibooki et al., 2002; Schulte-Herbrüggen et al., 2013). Because of rapid human population growth, use of more efficient hunting tools, and increased access to forests provided by infrastructure developments, the harvesting of wildlife is often unsustainable and has become one of the main threats to tropical biodiversity. This exploitation is a major cause of wildlife decline and defaunation (Dirzo et al., 2014). A study describing the contribution of overhunting on global-scale population declines and range contractions of 301 mammal species found that nearly all declines occurred in developing countries, where another major threat is habitat loss caused by deforestation, agricultural expansion, human encroachment and competition with livestock (Ripple et al., 2016). Based on direct observations, a literature review and interviews with hunters, the extirpation of large mammals in the Kilum-Ijim forest on Mount Oku in north-west Cameroon probably began in the early 2oth century, possibly starting with the loss of elephants Loxodonta africana, followed by buffalos Syncerus caffer nanus (since the 1980s) and other large and medium-sized mammals such as leopards Panthera pardus, chimpanzees Pan troglodytes and red river hogs Potamochoerus porcus (Maisels et al., 2001).

Kilum-Ijim forest, on Mount Oku and the nearby Ijim Ridge in the Cameroon mountains, is the largest remaining patch of Afromontane forest in West and Central Africa. The area is known for its rich diversity of endemic plant and animal taxa. Forty plant species endemic to Cameroon occur in Oku (Cheek et al., 200o), and the mountain harbours 31 of the 43 species of birds that are endemic to the country (Forboseh et al., 2003). It is probably the last stronghold for two of these endemic species, Bannerman's turaco Tauraco bannermani and the banded wattle-eye Platysteira laticincta, both categorized as Endangered on the IUCN Red List (IUCN, 2018). A recently updated checklist of amphibians from Oku included 50 species, five of which are endemic to the mountain, seven to the Banso-Bamenda Highlands and 18 to the Cameroon Volcanic Line (Doherty-Bone \& Gvoždik, 2017). 
Seventy-seven species of mammals have been recorded on Oku since 1950 (Maisels et al., 2001), comprising mostly small-bodied species primarily from the Rodentia, Soricomorpha and Chiroptera. There are no other reports on the status of mammal populations of Mount Oku, except for rodents and shrews (Denys et al., 2014; Ntoungwa et al., 2019). The most recent checklist of Oku rodents suggested that at least 27 species occur in the area. Seven species are endemic to the Banso-Bamenda Highlands (Denys et al., 2014), with four of them restricted to Mount Oku. Six species (all endemics except Lemniscomys mittendorfi) are categorized as Vulnerable or Endangered on the IUCN Red List, with a decreasing population trend (IUCN, 2018).

With a human population density of up to $400 / \mathrm{km}^{2}, \mathrm{Oku}$ village is one of the most densely populated areas in rural Africa, resulting in intense pressure on natural resources. Threats to the surrounding ecosystems include overgrazing by cattle and goats in grassland areas and montane forests, firewood harvesting, agriculture, bee keeping, debarking of Prunus trees for medicinal uses, and bushmeat hunting (Oates et al., 2004). In 1997 researchers found a large number of so-called rat-squashing traps in the forest, suggesting that small rodents were among the animals primarily targeted by hunters (Maisels et al., 2001). This pattern is not common in the Congo Basin forest block where most harvested mammals are large and medium-sized species (Ripple et al., 2016), and there are no published reports describing the hunting of rodents in the context of wildlife conservation in Central Africa. Small mammals can provide important ecological functions, including seed dispersal (Yi \& Zhang, 2008), pollination (Johnson \& Pauw, 2014), consumption of vegetation and invertebrates (Payne \& Longland, 2001) and soil disturbance (Teunkens, 2016). In addition, they are a primary food source for many other vertebrates including owls, diurnal birds, and micro- and mesocarnivores (Riegert et al., 2007). Rodent population declines and local extirpations can thus negatively affect ecosystems. Here we document rodent trapping in $\mathrm{Oku}$, based on data collected from local hunters.

\section{Study area}

Oku village, in the Bui and Boyo administrative subdivision of the Northwest Region of Cameroon (Central Africa), is at c. 2,000 $\mathrm{m}$ altitude on Mount Oku, within the BansoBamenda Highlands (Fig. 1). The equatorial climate of the region is characterized by a wet season of 7-8 months (c. April-November) and a dry season of 4-5 months (c. December-March). Mean annual rainfall is $2,427 \mathrm{~mm}$ and temperature during the dry season is $10-28^{\circ} \mathrm{C}$ (Forboseh \& Ikfuingei, 2001).

It is likely that before the increase of the human population and the development of agriculture in the 2oth century,

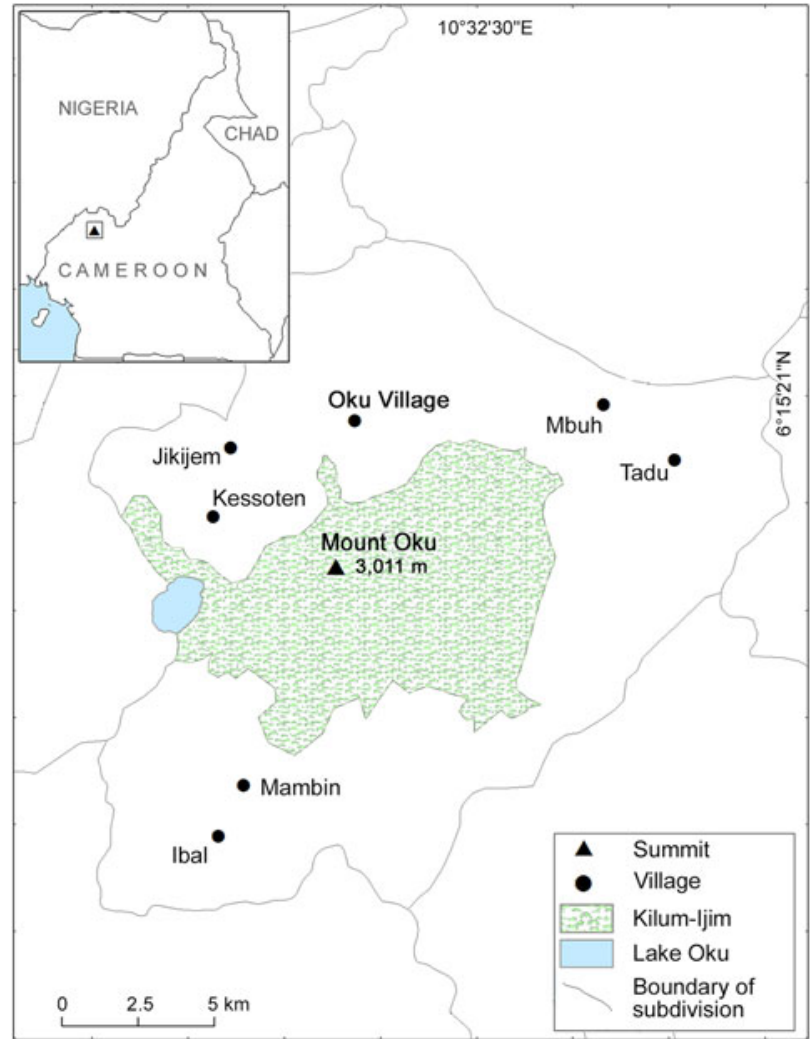

FIG. 1 Location of the study area in the Northwest Region of Cameroon.

the Banso-Bamenda Highlands were completely covered with forest (Cheek et al., 2000). The forested area was 20,000 ha in 1978 but had been reduced to c. 9,500 ha by 2012 (Momo et al., 2012). The remaining forests on Mount Oku are not part of any formally protected area. The vegetation has been described by Maisels \& Forboseh (1997), Cheek et al. (2000) and Asanga (2002). The Kilum-Ijim forest is a montane cloud forest, with a canopy dominated by upper montane forest species such as Podocarpus latifolius, Syzygium guineense, Schefflera mannii, Carapa grandiflora, Nuxia congesta, Prunus africana and Bersama abysinica. Since 1990 secondary forests have developed on former fallow lands, mainly characterized by heliophilous and fireresistant trees and shrubs (Gnidia glauca, Hypericum revolutum, Hypericum roeperianum, Maesa lanceolate, Erica mannii), and herbs of open habitats (Hyparrhenia sp., Sporobolus africanus, Pennisetum clandestinum).

\section{Methods}

\section{Data collection}

In January 2016, we interviewed 106 hunters local to Oku village. We divided the village into five areas and identified households with potential interviewees based on the 
local knowledge of ECK. We then randomly selected households with hunters from each of the five areas, to ensure representative coverage of the entire village. Participation was voluntary and each participant signed a document confirming informed consent before the interview started. Interviews lasted c. 1.5 hours and were in the local Lamnso language and/or English. We used a semistructured questionnaire with 21 questions that were organized into three sections to (1) capture the demographics of the population of local hunters, (2) examine their trapping activities and (3) explore the taxa of wild rodents captured, and their uses.

The first section comprised six questions, regarding the interviewee's (1) age, (2) sex, (3) marital status, (4) number of children, (5) educational level, and (6) primary occupation. The ten questions in the second section focused on the (1) number of years the interviewee had been trapping rodents, (2) target taxa, (3) main habitat chosen for trapping, (4) distance from village to the farthest trap, (5) changes in this distance over time, (6) types of trap used, (7) materials used for manufacturing traps, (8) number of traps set per week, (9) mean number of rodents trapped per week, and (10) changes in the number of rodents trapped over 1 year.

In the five questions of the third section we asked interviewees (1) to order 15 rodent taxa according to their capture frequency (we included all rodent taxa occurring in the area and limited the identification to genus level when it was difficult to distinguish the species in the local language), (2) in which habitats they trapped each of these taxa, (3) which was the main trapping season for each taxon, (4) about the uses of rodents trapped, and (5) whether they had perceived a decrease in the number of rodents harvested over time, with those who answered yes specifying whether the decrease had occurred during the last 5 years or over a longer period of time.

\section{Data analysis}

Upon examination of the data we found that some responses were unusable for further analysis, for example when the hunter chose none of the options or more than one, without providing clear reasons (Tables 1 \& 2). We categorized the hunters' age into six 10-year classes (ranging from 21 to $>70$ years; Table 1) and calculated the per cent of hunters in each class, and their mean age. We carried out the same calculations for the number of children in the hunter's family, and the number of rodents trapped per week. Papworth et al. (2009) reported the existence of a shifting baseline syndrome in two populations of hunters from Central Africa, mainly characterized by generational or personal amnesia. We therefore used a $\chi^{2}$ test, implemented in XLSTAT v.6.53470 (Addinsoft, Paris, France), to evaluate the effect of the hunters' age and their experience in rodent trapping on their responses. Further, we counted how many times each plant species used to construct traps was mentioned, and
TABLE 1 Demographics of 106 local hunters interviewed in Oku village, Cameroon. For each question the total number of valid responses received is given in parentheses. All respondents were men.

\begin{tabular}{lc}
\hline Question \& response options & No. of responses (\%) \\
\hline Age (years) (106) & $9(8.5)$ \\
$21-30$ & $21(19.8)$ \\
$31-40$ & $39(36.8)$ \\
$41-50$ & $18(17.0)$ \\
$51-60$ & $17(16.0)$ \\
$61-70$ & $2(1.9)$ \\
$>70$ & \\
Marital status (99) & $95(96.0)$ \\
Married & $2(2.0)$ \\
Single & $2(2.0)$ \\
Widowed & $0(0)$ \\
Divorced & \\
No. of children (106) & $32(30.2)$ \\
$<5$ & $54(50.9)$ \\
6-10 & $20(18.9)$ \\
$>10$ & \\
Educational level (106) & $21(19.8)$ \\
No formal education & $18(17.0)$ \\
Part primary school & $55(51.9)$ \\
Completed primary school & $10(9.4)$ \\
Part secondary \& high school & $2(1.9)$ \\
Completed secondary \& high school & $0(0)$ \\
University & \\
Primary occupation (91) & $78(85.7)$ \\
Farmer & $0(0)$ \\
Hunter & $3(3.3)$ \\
Shepherd & $0(0)$ \\
Trader & $5(5.5)$ \\
Traditional healer & $0(0)$ \\
Retired & $5(5.5)$ \\
Other & \\
\hline & \\
&
\end{tabular}

ranked them in order of importance based on the total counts. To analyse the relative importance of rodent taxa captured, we counted how many interviewees had listed each taxon in the seven most frequently trapped taxa. We converted answers of all closed questions to per cent, except for questions (2) and (4) of the third section (capture habitats of trapped taxa, and the use of rodents), for which we retained the data as final counts (i.e. absolute numbers; Table 3).

\section{Results}

\section{Demographics of local hunters}

Hunters were $22-71$ years old (mean $47 \pm$ SD 12 years), with $41-50$ years being the most common age class $(36.8 \%$; Table 1$)$. All hunters were male, most (96.0\%) were married, and most commonly (50.9\%) they had 6-10 children, with a mean of $7 \pm$ SD 3 children per family. More than half of the hunters $(51.9 \%)$ completed primary school, few attended some secondary and high school $(9.4 \%)$ or completed it 
TABLE 2 Characterization of trapping activities, based on interviews with 106 local hunters in Oku village. For each question the total number of valid responses received is indicated in parentheses. All interviewees stated to target rodents.

\begin{tabular}{|c|c|}
\hline Question \& response options & No. of responses (\%) \\
\hline \multicolumn{2}{|c|}{ Experience in rodent trapping (years) (106) } \\
\hline $0-5$ & $11(10.4)$ \\
\hline$>5-10$ & $15(14.2)$ \\
\hline$>10-15$ & $14(13.2)$ \\
\hline$>15-20$ & $21(19.8)$ \\
\hline$>20$ & $45(42.5)$ \\
\hline \multicolumn{2}{|l|}{ Main habitat for trapping (106) } \\
\hline Closed forest & $87(82.1)$ \\
\hline Open forest & $16(15.1)$ \\
\hline Bamboo forest & $3(2.8)$ \\
\hline Montane grassland & $0(0)$ \\
\hline Cropland & $0(0)$ \\
\hline \multicolumn{2}{|c|}{ Distance from village to furthest trap (106) } \\
\hline $0-2 \mathrm{~km}$ & $3(2.8)$ \\
\hline$>2-5 \mathrm{~km}$ & $17(16.0)$ \\
\hline$>5-10 \mathrm{~km}$ & $47(44.3)$ \\
\hline$>10 \mathrm{~km}$ & $39(36.8)$ \\
\hline \multicolumn{2}{|c|}{ Change in distance to furthest trap over time (106) } \\
\hline Increased & $56(52.8)$ \\
\hline Decreased & $12(11.3)$ \\
\hline No change & $38(35.9)$ \\
\hline \multicolumn{2}{|l|}{ No. of trap types used (105) } \\
\hline One & $90(85.7)$ \\
\hline Multiple & $15(14.3)$ \\
\hline \multicolumn{2}{|l|}{ No. of traps set per week (98) } \\
\hline$\leq 25$ & $0(0)$ \\
\hline $26-50$ & $2(2.0)$ \\
\hline $51-75$ & $3(3.1)$ \\
\hline $76-100$ & $6(6.1)$ \\
\hline$>100$ & $87(88.8)$ \\
\hline \multicolumn{2}{|c|}{ Mean no. of rodents trapped per week (106) } \\
\hline$\leq 25$ & $30(28.3)$ \\
\hline $26-50$ & $41(38.7)$ \\
\hline $51-75$ & $20(18.9)$ \\
\hline $76-100$ & $9(8.5)$ \\
\hline$>100$ & $6(5.7)$ \\
\hline \multicolumn{2}{|c|}{ Change in no. of rodents trapped over 1 year (106) } \\
\hline Decreased & $92(96.9)$ \\
\hline No change & $3(3.2)$ \\
\hline
\end{tabular}

(1.9\%). Twenty-one interviewees (19.8\%) had no formal education and none attended university. The primary occupation of most hunters was farming $(85.7 \%)$, followed by practicing traditional medicine $(5.5 \%)$, animal breeding $(3.3 \%)$, carpentry $(2.9 \%)$ and masonry $(2.6 \%)$. None of the interviewees indicated hunting or trade was their primary occupation.

\section{Trapping activities}

The majority of hunters $(62.3 \%)$ reported to have trapped rodents for $\geq 15$ years (Table 2). All hunters selected rodents as their target group. Most hunters set traps primarily in closed forest (82.1\%), some in open areas (15.1\%) and few in bamboo forests (2.8\%). Montane grassland and cropland were never the main hunting habitat. Of the 106 hunters, $>80 \%$ reported to regularly cover $\geq 5 \mathrm{~km}$ during trapping sessions, $44.3 \%$ covered $5-10 \mathrm{~km}, 36.8 \%$ travelled $>10 \mathrm{~km}$, $16.0 \%$ travelled $2-5 \mathrm{~km}$ and $2.8 \%$ covered $<2 \mathrm{~km}$. The hunters' age and years of trapping experience had no effect on any reported changes in the distance covered over time $\left(\chi^{2}\right.$ tests, $\mathrm{P}=0.332$ and 0.188 for age and years of trapping, respectively). Over half of the hunters $(52.8 \%)$ reported the distance travelled had increased over time, and 35.9 and $11.3 \%$ declared that the distance had remained the same or decreased over time, respectively.

Most hunters (85.7\%) reported using only one type of trap and $14.3 \%$ used multiple trap types. The traditional rodent trap used by local hunters consists of plant materials with a rock placed such that it will crush the animal passing through the trap. Ten plant species/taxa were mentioned as material used for building traps (Table 4). Of the 96 hunters who answered this question, most mentioned Raphia farinifera (Gaertn.) Hyl. (59 responses) and Xymalos monospora (Harv) Bail. (47 responses). The least mentioned species was Pittosporum viridiflorum Sims (5 responses). The majority $(87,88.8 \%)$ of hunters reported they set $\geq 100$ rodent traps per week, six hunters $(6.1 \%)$ reported $76-100$ traps, three hunters (3.1\%) used $26-50$ and two (2.0\%) set 51-75 traps per week. The most frequently reported range of the number of rodents trapped per week was $26-50$ (38.7\% of responses) and some hunters reported harvesting $>100$ rodents per week (Table 2). The mean number of rodents harvested per week was $38 \pm$ SD 11. Most (96.9\%) interviewees stated that the mean number of rodents harvested per week is not constant throughout the year, with more animals trapped during the rainy season.

\section{Rodent taxa trapped and their uses}

The distribution of responses regarding the primary trapping locations and the rank in the order of capture frequency is given in Table 3. Hunters reported harvesting five of the 15 taxa (P. hartwigi, Oenomys hypoxanthus, H. rufocanus, Lemniscomys spp., O. occidentalis) in all habitat types. Hylomyscus spp., L. okuensis and Cricetomys sp. were caught in all habitats except croplands, and $H$. rufocanus in all habitats except bamboo forests. Lophuromys spp. were primarily captured in cropland $(56$ mentions), mountain grasslands (24) and bamboo forest (12). Dasymys sp. was only captured in closed forest. Several taxa were not reported as being captured in any of those habitats (Mastomys spp., Mus spp., Grammomys spp., A. africanus and squirrels), although some of these were ranked among the most frequently harvested taxa. 
TABLE 3 The 15 rodent taxa included in the survey with 106 local hunters in Oku. The table shows the number of interviewees who reported capturing each taxon in different habitat types, and the number of interviewees who included each taxon amongst the top seven most frequently captured taxa. All interviewees reported capturing more individuals of all taxa during the rainy season.

\begin{tabular}{|c|c|c|c|c|c|c|c|c|c|}
\hline \multirow[b]{2}{*}{ Taxon } & \multirow{2}{*}{$\begin{array}{l}\text { Conservation } \\
\text { status (endemism/ } \\
\text { IUCN Red List } \\
\text { category }^{1} \text { ) }\end{array}$} & \multirow{2}{*}{$\begin{array}{l}\text { Total no. of } \\
\text { interviewees } \\
\text { capturing } \\
\text { the taxon }\end{array}$} & \multicolumn{5}{|c|}{$\begin{array}{l}\text { No. of interviewees } \\
\text { capturing the taxon } \\
\text { in habitat type }\end{array}$} & \multirow{2}{*}{$\begin{array}{l}\text { No. of interviewees } \\
\text { ranking the taxon in } \\
\text { top } 7 \text { most frequently } \\
\text { captured taxa }\end{array}$} & \multirow{2}{*}{$\begin{array}{l}\text { Rank in order } \\
\text { of capture } \\
\text { frequency }\end{array}$} \\
\hline & & & $\mathrm{CF}$ & $\mathrm{OF}$ & $\mathrm{BF}$ & MG & $\mathrm{C}$ & & \\
\hline Atherurus africanus & Not endemic/LC & 36 & 0 & 0 & 0 & 0 & 0 & 0 & 12 \\
\hline Cricetomys sp. & No species endemic/n.a. & 102 & 42 & 36 & 42 & 12 & 3 & 19 & 9 \\
\hline Dasymys sp. & No species endemic/n.a. & 18 & 30 & 0 & 0 & 0 & 0 & 0 & 12 \\
\hline Grammomys spp. & No species endemic/n.a. & 86 & 0 & 0 & 0 & 0 & 0 & 54 & 4 \\
\hline Hybomys rufocanus & Endemic to Cameroon Volcanic Line/not assessed & 102 & 6 & 12 & 0 & 45 & 42 & 46 & 5 \\
\hline Hylomyscus spp. & H. grandis endemic to $\mathrm{Oku} / \mathrm{EN}$ & 102 & 48 & 45 & 48 & 42 & 0 & 32 & 6 \\
\hline Lamottemys okuensis & Genus endemic to $\mathrm{Oku} / \mathrm{EN}$ & 102 & 48 & 45 & 48 & 42 & 0 & 58 & 2 \\
\hline Lemniscomys spp. & L. mittendorfi endemic to $\mathrm{Oku} / \mathrm{LC}$ & 102 & 36 & 35 & 12 & 36 & 18 & 0 & 12 \\
\hline Lophuromys spp. & L. dieterleni endemic to $\mathrm{Mt} \mathrm{Oku/EN}$ & 86 & 0 & 0 & 12 & 24 & 56 & 28 & 8 \\
\hline Mastomys spp. & No species endemic/n.a. & 102 & 0 & 0 & 0 & 0 & 0 & 31 & 7 \\
\hline Mus spp. & No species endemic/n.a. & 102 & 0 & 0 & 0 & 0 & 0 & 0 & 12 \\
\hline Oenomys hypoxantus & O. hypoxantus albiventris endemic to Oku/not assessed & 78 & 32 & 9 & 6 & 3 & 12 & 17 & 10 \\
\hline Otomys occidentalis & Endemic to Bamenda Highlands/VU & 102 & 42 & 36 & 9 & 39 & 21 & 57 & 3 \\
\hline Praomys hartwigi & Endemic to Bamenda Highlands/VU & 102 & 54 & 51 & 47 & 35 & 12 & 66 & 1 \\
\hline Squirrels & Paraxerus cooperi endemic to Cameroon Volcanic Line/DD & 102 & 0 & 0 & 0 & 0 & 0 & 16 & 11 \\
\hline
\end{tabular}

${ }^{1}$ DD, Data Deficient; LC, Least Concern; VU, Vulnerable; EN, Endangered; n.a., not applicable because the taxon was not identified to species level or contained several species in different Red List categories. ${ }^{2} \mathrm{CF}$, closed forest; $\mathrm{OF}$, open forest; $\mathrm{BF}$, bamboo forest; $\mathrm{MG}$, montane grassland; C, cropland. 
TABLE 4 Plant taxa used for the manufacture of rodent traps, based on interviews with 106 local hunters in Oku. None of these plants are endemic to the area, and none have been assessed for the IUCN Red List.

\begin{tabular}{ll}
\hline Taxon & No. of responses \\
\hline Raphia farinifera (Gaertn.) Hyl. & 59 \\
Xymalos monospora (Harv.) Bail. & 47 \\
Clematis hirsuta (Gill.) Perr. & 21 \\
Syzygium guineense (Wild.) D.C. & 18 \\
Rapanea melanophloeos (L.) Mez. & 15 \\
Arundinaria alpina (K. Schum.) & 12 \\
Cyperaceae & 12 \\
Entada abyssinica Stend ex A. Rich. & 12 \\
Podocarpus latifolius (Thumb.) R.G. ex Mirb. & 9 \\
Pittosporum viridiflorum Sims & 5 \\
\hline
\end{tabular}

All hunters reported that higher numbers of rodents, of all taxa, were captured in the rainy season. Praomys hartwigi was the most commonly trapped taxon. Other species frequently trapped were $H$. rufocanus, L. okuensis, and O. occidentalis; captures of Grammomys spp. and Hylomyscus spp. were less common.

Most hunters used the rodents captured for household consumption (91 mentions; $85.8 \%$ ) and trade (96; 90.6\%). Sixty-nine hunters (65.1\%) also mentioned the use of $P$. hartwigi in traditional medicine. The hunters' age and years of trapping experience had no effect on any perceived decrease in the number of rodents harvested over time $\left(\chi^{2}\right.$ tests, $\mathrm{P}=0.435$ and 0.368 for age and years of trapping, respectively). Most hunters $(87 ; 82.3 \%)$ had noticed a decrease in the number of rodents captured over time, with $25.3 \%$ reporting the decrease occurred in the last 5 years, and $57.0 \%$ stating the decrease had occurred over a longer period of time.

\section{Discussion}

Hunting of wild animals as a source of protein is common in humid forests in Africa, but the sustainability of the practice depends on the relationship between human and wildlife population densities (Fa et al., 2015). With a human population density of $300-400 / \mathrm{km}^{2}$, hunting in Oku has resulted in the local extirpation of most mammal species with a body weight $>200 \mathrm{~g}$ (Maisels et al., 2001), which has probably led to a shift towards the consumption of small mammals. Our findings suggest that rodent trapping is a regular practice in Oku that has probably been passed down generations for $>20$ years. Hunters were 22-71 years old, which represents at least three generations of hunters. Many $(42.45 \%)$ of the hunters interviewed reported to have trapped rodents for $>_{20}$ years. This long-term rodent trapping in Oku has put persistent pressure on rodent populations over an extended period of time. Previous studies have reported links between hunters' family size, their level of respon- sibility to provide for their family, and bushmeat hunting (Wright \& Priston, 2010). All hunters interviewed in our study were male, most were married, with a mean number of seven children per family, suggesting high levels of responsibility and thus reliance on wild meat for food security.

Education affects people's perceptions, with knowledge about the importance of biodiversity conservation being scarce in less educated communities (Anthony, 2007; Vodouhê et al., 2010). People with higher levels of formal education tend to be involved in more diverse activities that may benefit biodiversity conservation, including antipoaching activities, tourism, teaching, and working with conservation NGOs (Vodouhê et al., 2010). More highly educated people also have more diverse sources of income and rarely practice agriculture as their primary occupation. In Oku, the majority $(85.71 \%)$ of interviewed hunters were farmers and most had a low educational level (only c. 10\% were educated beyond primary school level), which is consistent with the finding of Vodouhê et al. (2010) suggesting that less educated communities are less aware of the importance of biodiversity conservation and more involved in bushmeat hunting. Local wildlife conservation authorities should monitor the education of local communities in Oku and take adequate measures to ensure the conservation of the area's biodiversity.

Our findings suggest that rodent trapping is a secondary activity, with rodents primarily used for household consumption (86\% of hunters) and as a source of additional income (91\%). The consumption of small rodents has not previously been noted as a common practice in Cameroon, or in tropical Africa more widely, because most hunters target larger animals (Fa et al., 2015). The most commonly consumed rodents are generally those with a relatively high body weight, such as grasscutters Tryonomys spp. and giant rats Cricetomys sp. (Assogbadjo et al., 2005). In Oku, however, small rodents are regularly targeted (see Supplementary Table 1 for the body weight of the 15 targeted taxa).

Most of the interviewed hunters $(>80 \%)$ reported covering a minimum distance of $5 \mathrm{~km}$ to set traps and nearly half suggested that the trapping distance had increased over time (this did not depend on the age of hunters or their experience in rodent trapping). Nearly $90 \%$ of hunters operated $\geq 100$ rodent traps per week, in which they caught a mean of c. 38 animals per week, and most had perceived a decrease in the number of rodents harvested over time. We thus suggest that rodent trapping in Oku requires conservation attention. Two quantitative indicators can be used for the offtake of terrestrial species: (1) mean body mass of harvested species across sites and dates, and (2) time series of the number of harvested individuals across species (Ingram et al., 2015). Our study was based on interviews conducted over 1 month; further studies over a longer period of time are needed to gather data on the number of individuals 
harvested for each species and their uses, to evaluate the trapping pressure for all rodent species in Oku, particularly those of conservation concern (i.e. categorized as threatened on the IUCN Red List). More specifically, rodent trapping needs to be monitored over an extended period of time, combined with more detailed interviews of hunters, to assess the sustainability of this practice in Oku. A previous study reported a combination of a large number of traps used (up to 200 traps per hunter per night) and a low rate of rodents harvested (5-10 rodents in each daily visit) as an indicator of high hunting pressure (Maisels et al., 2001). We found a large number of traps set and low trapping success (c. 5.4\% for a minimum effort of 100 trap nights), suggesting intense trapping pressure on the rodent populations of Oku.

Most interviewed hunters reported that they trapped principally in closed forest, and the plants used to build traps (except those of the family Cyperaceae) were also forest species. Nearly all rodent taxa captured by hunters were trapped in closed forest (except Lophuromys spp.), although many were also captured in other habitats. It is possible that the association between forests and the captured taxa is biased by the fact that most trappers are primarily hunting in forested areas. Some rodent species may be shifting their habitat usage in response to forest disturbance around $\mathrm{Oku}$, which could explain some of the less expected responses provided by hunters. For example, O. occidentalis is a typical grassland rodent but also occurs among ferns of montane forest clearings (Taylor \& Hutterer, 2008). A large proportion of hunters reported capturing this species in forested areas. To gain further insights, it would be useful to quantify the trapping effort in each habitat type and to correlate this with the trapping rate for each species.

A study in south-east Gabon reported an increased trapping rate of rodents in the rainy season, which correlated with breeding activities (Nicolas \& Colyn, 2003). Oku hunters reported harvesting more individuals of all taxa in the rainy season. Data on population dynamics of Oku rodents are needed for a detailed assessment of any pattern. The Vulnerable $P$. hartwigi and Endangered $L$. okuensis were the two most harvested species. Lamottemys okuensis is restricted to montane forest in an area of c. $100 \mathrm{~km}^{2}$ (Missoup et al., 2016). Given this limited distribution, the fact that it is one of the most commonly trapped rodents is of concern. Praomys hartwigi, the most harvested taxon, is also used locally for traditional medicine. There is an urgent need to collect data on the population trends and conservation status of these two species in Oku. We propose that an educational programme should be developed to sensitize the local population about negative effects of intensive rodent trapping on the biodiversity of Mount Oku. This should be combined with support for family planning and the development of alternative livelihood activities that could reduce the local community's dependence on bushmeat to meet their protein requirements.

Acknowledgements We thank the local hunters who participated in the study, and two anonymous reviewers for their critiques. Fieldwork was funded by the UNESCO-HP Project entitled Renforcement des capacités locales pour l'étude des changements climatiques et de leurs conséquences multiformes à travers le calcul distribué avec le concours de la diaspora, directed Robert Mbiake.

Author contributions Study design: ADM, ND, CD; data collection: ECK; data analysis: ADM, CD, ND; writing: ADM.

\section{Conflict of interest None.}

Ethical standards This research abided by the Oryx guidelines on ethical standards and was conducted under a permit (No 41/ MINRESI/B00/C00/C40) from the Ministry of Scientific Research and Innovation. The researchers obtained prior, voluntary and informed consent from each of the study participants before the interviews.

\section{References}

Anthony, B. (2007) The dual nature of parks: attitudes of neighbouring communities towards Kruger National Park, South Africa. Environmental Conservation, 34, 236-245.

AsANGA, C. (2002) Case Study of Exemplary Forest Management in Central Africa: Community Forest Management at the Kilum-Ijim Mountain Forest Region, Cameroon. Working Paper FM/11. Food and Agriculture Organization of the United Nations, Rome, Italy. Assogbadjo, A.E., Codjia, J.T.C., Sinsin, B., Ekue, M.R.M. \& Mensah, G.A. (2005) Importance of rodents as a human food source in Benin. Belgian Journal of Zoology, 135, 11-15.

Bowen-Jones, E., Brown, D. \& Robinson, E.J.Z. (2003) Economic commodity or environmental crisis? An interdisciplinary approach to analysing the bushmeat trade in central and West Africa. Area, $35,390-402$.

Brashares, J.S. (2004) Bushmeat hunting, wildlife declines, and fish supply in West Africa. Science, 306, 1180-1183.

Cheek, M., Onana, J.-M. \& Pollard, B.J. (20oo) The Plants of Mt Oku and the Ijim Ridge: A Conservation Checklist. Royal Botanic Gardens, Kew, UK.

Denys, C., Missoup, A.D., Nicolas, V., Fülling, O., Delapré, A., Bilong Bilong, C.F. et al. (2014) African highlands as mammal diversity hotspots: new records of Lamottemys okuensis (Rodentia: Muridae) and other endemic rodents from Mount Oku, Cameroon. Zoosystema, 36, 647-69o.

Dirzo, R., Young, H.S., Galetti, M., Ceballos, G., Isaac, N.J.B. \& Collen, B. (2014) Defaunation in the Anthropocene. Science, 345, 401-406.

Doherty-Bone, T.M. \& Gvoždík, V. (2017) The Amphibians of Mount Oku, Cameroon: an updated species inventory and conservation review. Zookeys, 643, 109-139.

FA, J. \& NASI, R. (2015) The Role of Bushmeat in Food Security and Nutrition. XIV World Forestry Congress, Durban, South Africa, 7-11 September 2015.

Fa, J.E., Olivero, J., Real, R., Farfán, M.A., Márquez, A.L., VARGAS, J.M. et al. (2015) Disentangling the relative effects of bushmeat availability on human nutrition in Central Africa. Scientific Reports, 5, 8168.

Forboseh, P.F. \& Ikfuingei, R.N. (2001) Estimating the population densities of Tauraco bannermani in the Kilum-Ijim forest, Northwestern Cameroon. Ostrich, 15, 114-118. 
Forboseh, P.F., Keming, E.C., Toh, C.L. \& Wultof, I.N.B. (2003) Monitoring of Kilum-Ijim forest bird communities: initial findings. Bird Conservation International, 13, 255-271.

Ingram, D.J., Coad, L., Collen, B., Kümpel, N.F., Breuer, T., FA, J.E. et al. (2015) Indicators for wild animal offtake methods and case study for African mammals and birds. Ecology and Society, 20, 40.

IUCN (2018) The IUCN Red List of Threatened Species 2018. iucnredlist.org [accessed 22 November 2018].

Johnson, C.M. \& PAUw, A. (2014) Adaptation for rodent pollination in Leucospermum arenarium (Proteaceae) despite rapid pollen loss during grooming. Annals of Botany, 113, 931-938.

Junker, J., Boesch, C., Mundry, R., Stephens, C., Lormie, M., TweH, C. et al. (2015) Education and access to fish but not economic development predict chimpanzee and mammal occurrence in West Africa. Biological Conservation, 182, 27-35.

Loibooki, M., Hofer, H., Campbell, K.L.I \& East, M.L. (2002) Bushmeat hunting by communities adjacent to the Serengeti National Park, Tanzania: the importance of livestock ownership and alternative sources of protein and income. Environmental Conservation, 29, 391-398.

Maisels, F. \& Forbosen, P. (1997) Vegetation Survey: Ecological Monitoring Programme 1997. Technical report, Ecomonitoring programme, Kilum-Ijim Forest Project. BirdLife International, Cambridge, UK, and Ministry of Environment and Forestry, Yaoundé, Cameroon.

Maisels, F.G., Keming, E., Kemei, M. \& Toh, C. (2001) The extirpation of large mammals and implications for montane forest conservation: the case of the Kilum-Ijum Forest, North-west Province, Cameroon. Oryx, 35, 322-331.

Milner-Gulland, E.J., Bennett, E.L. \& The SCB 2002 Annual Meeting Wild Meat Group (2003) Wild meat: the bigger picture. Trends in Ecology \& Evolution, 18, 351-357.

Missoup, A.D., Nicolas, V., Eiseb, S., Keming, C.E. \& Denys, C. (2016) Phylogenetic position of the endemic Mount Oku rat, Lamottemys okuensis (Rodentia: Muridae), based on molecular and morphological data. Zoological Journal of the Linnean Society, 177, 209-226.

Momo, S.M.C., Chabrerie, O., Gallet-Moron, E., Nkongmeneck, B.-A., Leumbe Leumbe, O.N. \& Decoce, G. (2012) Analyse de la dynamique de déforestation par télédétection couplée aux modèles d'équations structurales: exemple de la forêt néphéliphile du mont Oku (Cameroun). Acta Botanica Gallica, 159, 451-466.

Nicolas, V. \& Colyn, M. (2003) Seasonal variations in population and community structure of small rodents in a tropical forest of Gabon. Canadian Journal of Zoology, 81, 1034-1046.
Ntoungwa Ebague, G.M., Missoup, A.D., Keming Chung, E., Tindo, M. \& Denys, C. (2019) Terrestrial small mammal assemblage from pellets of three sympatric owl species in the Mount Oku area (Northwest Cameroon), with implication for conservation. Bonn Zoological Bulletin, 68, 13-19.

Oates, J.F., Bergl, R.A. \& Linder, J.M. (2004) Africa's Gulf of Guinea Forests: Biodiversity Patterns and Conservation Priorities. Advances in Applied Biodiversity Science. Conservation International, Washington, DC, USA.

Papworth, S.K., Rist, J., Coad, L. \& Milner-Gulland, E.J. (2009) Evidence for shifting baseline syndrome in conservation. Conservation Letters, 2, 93-100.

Payne, S. \& Longland, W.S. (2001) Patterns of ectomycorrhizal-fungi consumption by small mammals in remnant old-growth forests of the Sierra Nevada. Journal of Mammalogy, $82,681-689$.

Riegert, J., Sedlàcek, O. \& Hutterer, R. (2007) Diet of sympatric African grass owl (Tyto capensis) and spotted eagle owl (Bubo africanus) in the Bamenda Highlands, NW Cameroon. African Journal of Ecology, 46, 428-431.

Ripple, W.J., Abernethy, K., Betts, M.G., Chapron, G., Dirzo, R., Galetti, M., Levi, T. et al. (2016) Bushmeat hunting and extinction risk to the world's mammals. Royal Society Open Science 3, 160498 .

Schulte-Herbrüggen, B., Cowlishaw, G., Homewood, K. \& Rowcliffe, J.M. (2013) The importance of bushmeat to the livelihoods of West African crash-crop farmers living in a faunally-depleted landscape. PLOS ONE, 8, e72807.

Taylor, P.J. \& Hutterer, R. (2008) Otomys occidentalis. In The IUCN Red List of Threatened Species 2008, dx.doi.org/10.2305/ IUCN.UK.2008.RLTS.T15657A4965956.en [accessed 27 December 2018].

Teunkens, B. (2016) The role of small rodents in ecosystem assembly. Do mice stimulate soil development by transporting soil mesofauna to restored sites? MSc thesis. University of Antwerp, Antwerp, Belgium.

Vodouhê, F.G., Coulibaly, O., Adégbidi, A. \& Sinsin, B. (2010) Community perception of biodiversity conservation within protected areas in Benin. Forest Policy and Economics, 12, 505-512.

Wright, J.H. \& Priston, N.E.C. (2010) Hunting and trapping in Lebialem Division, Cameroon: bushmeat harvesting practices and human reliance. Endangered Species Research, 11, 1-12.

YI, X.F. \& ZHANG, Z.B. (2008) Seed predation and dispersal of glabrous filbert (Corylus heterophylla) and pilose filbert (Corylus mandshurica) by small mammals in a temperate forest, northeast China. Plant Ecology, 196, 135-142. 